\title{
LUT
}

University

Understanding the practice of performance measurement in industrial collaboration: from design to implementation

Ukko Juhani, Saunila Minna

This is a Post-print

version of a publication

published by Elsevier

in Journal of Purchasing and Supply Management

DOI: $10.1016 / j . p u r s u p .2019 .02 .001$

Copyright of the original publication: (c) 2019 Elsevier Ltd.

Please cite the publication as follows:

Ukko, J., Saunila, M. (2019). Understanding the practice of performance measurement in industrial collaboration: from design to implementation. Journal of Purchasing and Supply Management. DOI: 10.1016/j.pursup.2019.02.001

This is a parallel published version of an original publication. This version can differ from the original published article. 


\section{Understanding the practice of performance measurement in industrial collaboration: from design to implementation}

This study focuses on the design and implementation of a performance measurement system (PMS) for industrial collaboration. This article provides insights from two case studies of industrial collaboration. The research aims to study the crucial characteristics of PMS design and implementation in industrial collaboration, in which multiple tiers, extending beyond the buyersupplier dyad, are considered. Prerequisites and challenges are crucial characteristics that should be examined in the design and implementation of a PMS. The results indicate three main characteristics affect the design and implementation of a PMS in an industrial collaboration: 1) the importance of collaboration, 2) the importance of coordination and integrated information systems within the system implementation, and 3) the importance of acknowledging the impact of varied customer needs.

Keywords: Performance Measurement; Performance Management; Industrial Collaboration; Supply Chain; Performance Measurement System; Buyer-Supplier Relationship

\section{Introduction}

The movement of industrial companies toward servitization has created new approaches to providing value through providing services that complement traditional products (Lovelock and Gummesson, 2004; Bititci et al., 2012; Cavalieri and Pezzotta, 2012; Ukko et al., 2015). Such companies work in a competitive and turbulent environment that requires they collaborate to respond to customers' demands more effectively and efficiently (Bititci et al., 2004). The shift from simple (collaborative) organizations involving a few partners to complex systems of organizations working together to create value (Bititci et al., 2012) has created new prerequisites for collaboration between customers and suppliers. This open and networked operating environment makes new demands on organizational members' abilities to work collaboratively with outsiders, and organizations find it challenging to manage their own processes in parallel with the surrounding operating environment (Ramsay and Wagner, 2009; Pekkola and Ukko, 2016). Creating and sustaining competitive advantage through collaboration requires that the 
collaboration structures be understood, managed, and measured (Verdecho et al., 2009). Therefore, companies must have effective and efficient performance measurement systems (PMSs). Despite the significance of collaboration as an economic engine for industrial companies, performance measurement theory has not provided extensive evidence that can help guide, monitor, and measure such entities.

Most of the previous studies on PMSs in industrial collaborations focused on supply chain performance measurement systems (SCPMSs), where only the point of view of the buyer company evaluating its suppliers is considered (Maestrini et al., 2018). Thus far, a measurement system in which both parties, the buyer and the customer, take an active role in the measurement process and collaborate in performance has not been thoroughly investigated (Koufteros et al., 2014; Melnyk et al., 2014; Maestrini et al., 2018). Even fewer studies on PMSs have been reported in which multiple tiers are considered, extending beyond the buyer-supplier dyad and configuring a multitier SCPMS (Maestrini et al., 2017). Based on this unexplored issue, they present a research gap regarding how multitier SCPMSs can be adopted, and the barriers and enablers.

This study focuses on the design and implementation of a PMS for industrial collaboration, in which the purpose of the system is similar to the purpose of a multitier SCPMS. The research aims to study the crucial characteristics of PMS design and implementation in this type of industrial collaboration. Recent studies on industrial collaboration highlight that companies operating in maintenance collaborations confront increasingly complex and dynamic interactions. This transition is due to the increasing trends of digitalization and outsourcing of maintenance. For example, instead of conducting maintenance on their own, factories buy the maintenance work from their equipment providers or companies specialized in industrial maintenance that sell service agreements or operating services for industrial plants. Managing such a transition requires strong collaboration, and these collaborations can also be significant in monetary terms. Although some studies concluded that performance measurement in such collaborations is important (Angerhofer and Angelides, 2006; Koufteros et al., 2014; Ukko and Pekkola, 2016; Maestrini et al., 2017), limited insights into the characteristics of PMS design and implementation in such collaborations exist. Thus, this study contributes by investigating PMS design and implementation in an empirical setting in the context of a business-to-business (B2B) industrial collaboration, in which multiple 
tiers are considered, extending beyond the buyer-supplier dyad. We consider prerequisites and challenges crucial characteristics that should be examined in the design and implementation of a PMS. The research questions are as follows:

RQ1. What are the prerequisites and challenges in the design and implementation of a PMS in an industrial collaboration?

RQ2. How can the prerequisites and challenges be managed in the design and implementation of a PMS in an industrial collaboration?

In justifying the research design, it is apparent that by systematically developing a collaboration between relevant partners, companies can significantly improve the performance and competitiveness of their overall operations (Papakiriakopoulos and Pramatari, 2010; Liang, 2015). Furthermore, one aspect of the development of collaboration, which subsequently creates competitive advantages through collaboration, is to create appropriate tools for managing and measuring this type of development (Verdecho et al., 2009). The empirical part of this study is conducted using two case studies pertaining to industrial collaboration. The article provides insights regarding collaboration in the energy industry, involving four companies, as well as the mining industry, involving three companies.

The challenges that companies face have not been exhaustively studied; thus, it is crucial to understand the factors that characterize the design and implementation process for a PMS in industrial collaboration. In the literature section, the prerequisites and challenges of the PMS design and implementation are thoroughly analyzed, beginning with single companies, continuing with supply chains, and ending with industrial collaborations. In the results and discussion sections, the characteristics of the PMS design and implementation are discussed and compared with previous theory.

This article is structured as follows. First, a review of the literature on traditional performance measurement is conducted, beginning with single organizations and then focusing on supply chains and industrial collaborations. Section 3 describes the research methodology, and the results, in terms of the prerequisites and challenges of a PMS design and implementation in the context of 
industrial collaboration, are presented in section 4. The paper concludes with a discussion of the implications of the work and recommendations for further research.

\section{Literature review}

\subsection{Performance measurement}

Neely et al. (1995) consider performance measurement as the process of quantifying action, where measurement is the process of quantification and action leads to performance. A PMS can be defined as the set of metrics used in this process. Neely et al. (1995) also show that a PMS can be examined at three levels: (1) individual performance measures, (2) a set of performance measures, and (3) the relationship between the PMS and the environment within which the PMS operates. In this study, the second level (performance measures) is the focus, and to some extent, the third level (e.g., customer variety in different industrial collaborations). Bourne et al. (2000) contend that the development of a PMS can be divided into three main phases: (1) the design of the performance measures (designing measures and identifying key objectives), (2) the implementation of the performance measures (in data collection, collation, sorting, and distribution), and (3) the use of the performance measures (for measurement, review, action, and reflection). This study focuses mainly on design and implementation of a PMS. Further, one way to understand how a PMS is designed, implemented, and used is to categorize its key factors to contextualize, process, and understand the measurement content (Pettigrew et al., 1989; Bourne et al., 2002; Cuthbertson and Piotrowicz, 2011; Pekkola and Ukko, 2016). Defining the conditions in which the measurement takes place, how the measurement is carried out, and what is measured are important.

When the barriers of the design phase were discussed, it has been suggested that the measures chosen have been poorly defined (Schneiderman, 1999; Bourne et al., 2002) and that there has been too much focus on financial measures, which has encouraged short-termism and local optimization (Neely et al., 1995; Neely, 1999). This, in turn, has led to a lack of information about what customers want and how competitors perform (Kaplan and Norton 1992; Neely et al., 1995; Neely, 1999). This may result from a lack of strategic focus or actionable vision and strategy, which creates difficulty determining the relative importance of measures and identifying true 
drivers (Kaplan and Norton, 1996; Bierbusse and Siesfeld, 1997; Schneiderman, 1999; Bourne et al., 2002). The goals identified in the PMS design process have also been found to be negotiated rather than based on stakeholder requirements, and the large number of measures diluted the overall impact (Bierbusse and Siesfeld, 1997; Schneiderman, 1999; Bourne et al., 2002). Further, the lack of strategy links to department, team, and individual goals has been shown to be a barrier to the design of a successful PMS (Kaplan and Norton, 1996; Bourne et al., 2002; Ukko et al., 2007).

Considering the facilitators of a PMS design, Neely et al. (2000) argue that performance measures should be derived from the company's strategy. The senior management and the senior managers who drive the measurement activities facilitate the design process (Kennerley and Neely, 2002; Bourne, 2005). Everyone, including customers, employees, and managers, should be involved in selecting the measures (Neely et al., 2000; Kennerley and Neely, 2002; Ukko and Pekkola, 2016). Bourne et al. (2000) support this argument and suggest that designing a PMS is principally a cognitive exercise of translating customer views and stakeholder needs into business objectives and appropriate performance measures. Considering the movement from design to implementation, Neely et al. (2000) conclude that the process of designing a measurement system is intellectually challenging, fulfilling, and immensely valuable to managers who participate fully in it. However, the authors caution that increasing anecdotal evidence suggests that the process of designing a measurement system is not the most difficult task. Instead, the real challenges occur once managers have developed their robust measurement system, for then they must implement the measures. As soon as managers seek to do so, they encounter fear, company politics, and subversion (Neely et al., 2000).

The barriers to implementing a PMS include the effort required for the implementation, the ease of data accessibility through information technology (IT) systems, the personal consequences of measurement (Bourne et al., 2002; Bourne, 2005), time-consuming and costly data collection, inflexible IT systems (Bierbusse and Siesfeld; 1997; Bourne et al., 2002; Kennerley and Neely, 2002; Nudurupati and Bititci, 2005), lack of leadership, and resistance to change (Meekings, 1995; Bourne et al., 2002). Overlapping projects can also be a barrier to implementing this system (Bourne et al., 2000). Many factors can help overcome these challenges and facilitate the 
implementation of a PMS. For example, integration of the measurement with strategy development and business process review, commitment by senior management, perseverance, and a paternalistic company culture have been found to be facilitators of implementation (Bourne et al., 2002; Kennerley and Neely, 2002; Bourne, 2005). Bourne et al. (2002) showed that in successful companies, a PMS was implemented with the aim of "managing [the] business better," a higher goal than "improving the measurement system" (Bourne et al., 2002). A paternalistic culture was seen as it reduced the fear of measurement and therefore, resistance to the implementation (Bourne et al., 2002).

\subsection{Performance measurement in supply chains}

Another established stream of literature addresses the process of SCPM from design to implementation. Angerhofer and Angelides (2006) define a collaborative supply chain as "a system of interlinkages and inter-relationships of the stakeholders along with the processes undertaken, its supporting technology and the business strategy employed." Managing a supply chain requires understanding the inter-organizational management of the flow of goods and related information, which ensures performance and customer achievements for the organizations involved (Hofmann and Locker, 2009). Hofmann and Locker (2009) define SCPM as the collaborative process of quantifying the effectiveness and efficiency of actions in the supply chain, in which effectiveness expresses how well customers' requirements are met, and efficiency measures how resources are allocated economically within the supply chain when it provides a pre-specified level of customer satisfaction.

The challenges of SCPM are amplified by increased pressure to measure partnership, collaboration, agility, and business excellence requirements (Akyuz and Erkan, 2010). The process for selecting measures for SCPM attention should be guided by organizational goals and objectives, the type of business, the nature of the market, and technological competence (Gunasekaran and Kobu, 2007). This means that SCPM must be developed throughout the supply chain. All participants in the supply chain should be involved and committed to common goals, such as increased customer satisfaction throughout the supply chain and enhanced competitiveness 
(Gunasekaran et al., 2004). Thus, SCPM requires a complete and dynamic approach throughout the supply chain based on sound practices (Gunasekaran et al., 2004; Akyuz and Erkan, 2010).

As a response to these challenges, most of the studies related to SCPM discuss what to measure and provide valuable information and guidelines for designing a PMS (Papakiriakopoulos and Pramatari, 2010). Previous research focused on diverse methods of classifying measures (Beamon, 1999; Gunasekaran et al., 2001; Chan, 2003; Gunasekaran et al., 2004; Aramyan et al., 2007), but the common understanding has been that a balanced set of measures should be utilized. Some researchers separate qualitative and quantitative measures (Beamon, 1999; Chan, 2003), whereas others distinguish between measures that focus on strategy, operations, or tactics (Gunasekaran et al., 2001; Gunasekaran et al., 2004; Gunasekaran and Kobu, 2007).

Gunasekaran and Kobu (2007) present that operations-level measurement has received significant attention from researchers and practitioners, but the strategic and tactical levels need more attention due to their significance in supply chains. Similarly, Chelariu et al. (2014) suggested that SCPM focuses primarily on operational and economic performance measures while paying less attention to relational and strategic performance measures. The main obstacle to using such qualitative, forward-looking indicators is the difficulty of quantifying these measures (Aramyan et al., 2007). Challenges to a PMS can also result when the strategy and measurements are not connected, when a biased focus on financial metrics occurs, and when there are too many isolated and incompatible measures or problems in a supply chain system (Gunasekaran and Kobu, 2007). However, the current literature provides examples of the positive effects of aligning strategic goals and performance measurements. For example, Pohl and Förstl (2011) find that a purchasing PMS aligns the purchasing strategy with the segmented-product or service-category strategies.

Other research has highlighted important issues during the implementation of SCPM (Papakiriakopoulos and Pramatari, 2010). Charan et al. (2008) found that awareness of SCPM systems is a very significant driver of implementation. They suggest that senior management should focus on improving the awareness of PMSs in supply chains, encouraging commitment among senior management, ensuring consistency with strategic goals, allocating funding for implementing PMSs, and designing effective information systems. Akyuz and Erkan (2010) 
contend that implementation requires considering business process management and technical and organizational/managerial issues simultaneously. In addition to business process management, Papakiriakopoulos and Pramatari (2010) emphasize the importance of collaboration and data management in implementing an SCPM system. They consider collaboration the main driver for implementing a PMS because collaboration is the common objective of all parties although they have their own mechanisms and identify areas to improve in different ways (Papakiriakopoulos and Pramatari, 2010). In addition, collaboration, aided by information sharing, improve the performance of a supply chain (Papakiriakopoulos and Pramatari, 2010; Liang, 2015). The role of a PMS is crucial as it impacts the dynamics between two parties (Nollet et al., 2017). A PMS can assist the collaborating partners in re-evaluating their collaboration objectives, shifting the focus from timely information sharing to enhancing the quality of the information. This then helps the partners re-examine the scope of the collaboration through the incorporation of new business processes (Papakiriakopoulos and Pramatari, 2010).

The second driver of SCPM implementation, data management, includes all the actions performed during the life cycle of shared data (Papakiriakopoulos and Pramatari, 2010). This includes, for example, adequate IT systems. At the operations level, IT systems are especially important in supply chains as the systems are used to link a company to its partners and act as an effective communication infrastructure by assisting in information sharing (Angerhofer and Angelides, 2006; Lu et al., 2006; Papakiriakopoulos and Pramatari, 2010; Liang, 2015). Angerhofer and Angelides (2006) contend that enabling technologies such as IT systems are also important at the management and strategy levels. At the management level, systems can assist in planning and coordination by providing relevant and accurate information in a timely manner. At the strategic level, they can be used to support decision-makers in strategic decisions that have predominantly long-term effects (Angerhofer and Angelides, 2006). Although information sharing is considered crucial in SCPM, Hofmann and Locker (2009) point out that as long as companies consider their suppliers and customers to be opponents rather than partners, the necessary data exchange cannot take place. This point highlights the importance of true collaboration and shared goals.

The third driver of the implementation of SCPM systems, business process management, reflects the business processes that are not part of the collaboration (Papakiriakopoulos and Pramatari, 
2010). Although there is a growing body of literature on SCPM systems ranging from design to implementation, case studies that validate theory and extract knowledge regarding the implementation and use of a PMS in a real operating environment are lacking (Papakiriakopoulos and Pramatari, 2010).

\subsection{Performance measurement in industrial collaboration}

It is commonly accepted that to survive in a competitive environment, companies must collaborate to meet customers' needs more effectively and efficiently (Bititci et al., 2007, 2012). Collaboration can be defined in many ways, but it generally refers to working together for mutual benefit (Huxham, 1996; Parung and Bititci, 2006; Camarinha-Matos et al., 2009). The collaboration question is no longer about whether to collaborate but about the need to understand and select suitable options (Pisano and Verganti, 2008; Bititci et al., 2012). Thus, if companies aim to create and sustain a competitive advantage through collaboration, their collaboration structures should be understood, measured, and managed; otherwise, the objectives will not be achieved, and the collaboration will fail (Verdecho et al., 2009; Pekkola and Ukko, 2016).

It has been suggested that collaborative performance measurement can drive networks to change the focus of network management from contribution and operations to joint strategy and commitment (Kaplan et al., 2010). Papakiriakopoulos and Pramatari (2010) describe a collaborative PMS as a set of measures used to quantify the efficiency or effectiveness of purposeful joint actions. For example, a collaborative PMS could be used to manage business processes and guide actors to pursue common targets for collaboration (Beamon, 1999; Leseure et al., 2001; Busi and Bititci, 2006; Kulmala and Lönnqvist, 2006). Based on the objective of the collaboration, the measures monitor external relations and the efficiency of internal and extended processes (Busi and Bititci, 2006). Collaboration can also be more structured and mature, with entities sharing information, resources, and responsibilities to jointly plan, implement, and evaluate a program of activities to achieve a common goal, thus generating value (CamarinhaMatos et al., 2009). After considering the implications, Mahama (2006) showed that a PMS facilitates cooperation and socialization in inter-organizational relationships and helps ensure that performance information is distributed fairly among the participants, thus facilitating learning and 
problem solving within the network. The factors influencing performance management are enterprise collaboration, operations management and business process management/engineering, performance measurement/management and decision support, information and communication management, and organizational behavior and knowledge management (Busi and Bititci, 2006). Busi and Bititci (2006) claim that all of these elements should be analyzed to develop measures for collaborative performance management.

Bititci et al. (2012) emphasize that future research on the design of a collaborative PMS should focus on understanding collaboration and its mechanisms and on developing theories, methods, and techniques to ensure that all network partners can define, manage, measure, and evaluate common goals and responsibilities. A collaborative PMS should be designed to utilize a balanced set of performance measures that monitor external relationships and the efficiency of internal and extended processes, which will support proactive management based on feedback and feedforward operations control (Busi and Bititci, 2006). Regarding a balanced set of performance measures, Parung and Bititci $(2006,2008)$ propose numerous value generators in addition to financial assets (e.g., physical assets and human, organizational, and relational capital) because the extant literature and empirical evidence on collaborative performance measurement seem limited to financial measures (Kald and Nilsson, 2000; Leseure et al., 2001; Håkansson and Lind, 2004). The success of a collaboration and its measurement can be examined through the following: (1) the input of each participant in the collaboration, (2) the health of the collaboration, and (3) the outcome of the collaboration (Parung and Bititci, 2008). Measuring the input focuses on the resources the participants contribute to the collaborative network. Assessing the health of a collaborative network entails measuring the dimensions commitment, coordination, trust, quality of communication, and participation, as well as the presence of the conflict resolution technique of joint problem solving (Parung and Bititci, 2006, 2008). Measuring the output determines the benefit accrued to the key stakeholders as a result of their participation in the collaboration. According to Parung and Bititci (2006), the outcome of the organization is usually associated with its performance, and performance measurement is often linked to the efficiency and effectiveness of an organization as it works to satisfy its customers (Neely, 1999). To evaluate the benefits for participants who join collaborative networks, the output should be measured before and after the collaboration (Parung and Bititci, 2006). It has also been found that when designing a PMS, 
collaborations face difficulty evaluating and determining the unit of analysis (Beamon, 1999; Busi and Bititci, 2006).

Busi and Bititci (2006) emphasize that the difficulties of developing a collaborative culture and appropriate performance measures have been major barriers to the successful implementation of a collaborative PMS. Thus, determining the key elements of collaboration, the ways in which these elements interact, and the ways in which the elements can be integrated within a PMS is necessary. Radnor and Barnes (2007) contend that in addition to the measurement (which includes reporting and performance management), the actions taken should be considered. Henri (2006) reveals that the effectiveness of a PMS depends on the availability of the right information attributes, as well as how companies use these attributes. Given the dynamics of today's service environment, a more interactive information exchange process based on a broader scope of information is required to identify the right approach for capturing opportunities and positioning businesses (Amir, 2014). Thus, developing a suitable communication infrastructure is necessary. The network must have a clear vision regarding the roles and targets of the network and an understanding of and commitment to the shared objectives.

To overcome these challenges when designing and implementing a collaborative PMS, Ukko et al. (2015) propose that the state of the collaboration, the services provided, and mutual values need to be defined collaboratively before the design process for the actual measures begins. Niebecker et al. (2010) present that the different organizations in collaboration typically define their individual strategies and goals for the collaboration first and then identify and consolidate common strategies and goals with their partner. This method helps prevent misunderstandings and ambiguous shared project goals and common measures. Niebecker et al. (2010) also observe that the partners need to come together to discuss and clarify their common project goals and strategies before the project is in progress. The project partners define common key performance indicators (KPIs) to measure the project targets, and at the same time, the project partners define corrective actions for when the KPIs are not met. Further, the partners need to develop strategy maps. By collaborating, the partners can exchange and synchronize these KPIs without threatening each company's know-how and information protection, as only relevant and predefined indicators are monitored and controlled. Thus, each partner's alignment to business strategies and project goals 
can be assured, stakeholder commitment ensured, and measures defined and used collaboratively (Niebecker et al., 2008, 2010). Baines and Lightfoot (2014) emphasize the need to adopt performance measures that reflect outcomes aligned to individual customers, and these performance measures are then disseminated throughout the extended processes of different organizations. Measures at different levels are needed to align operations to serve customers in terms of the outcomes the customers desire (Baines and Lightfoot, 2014).

\section{$2.4 \quad$ Research framework}

In the literature section, previous studies about the characteristics of a PMS design and implementation were examined beginning with single companies, continuing with supply chains, and ending with industrial collaborations. Next, these characteristics were reanalyzed to create the research framework presented in Table 1. In this table, the characteristics are presented in terms of the prerequisites and challenges, in which the prerequisites are considered drivers of PMS design and implementation, and the challenges are barriers to PMS design and implementation.

Table 1. Overview of current research

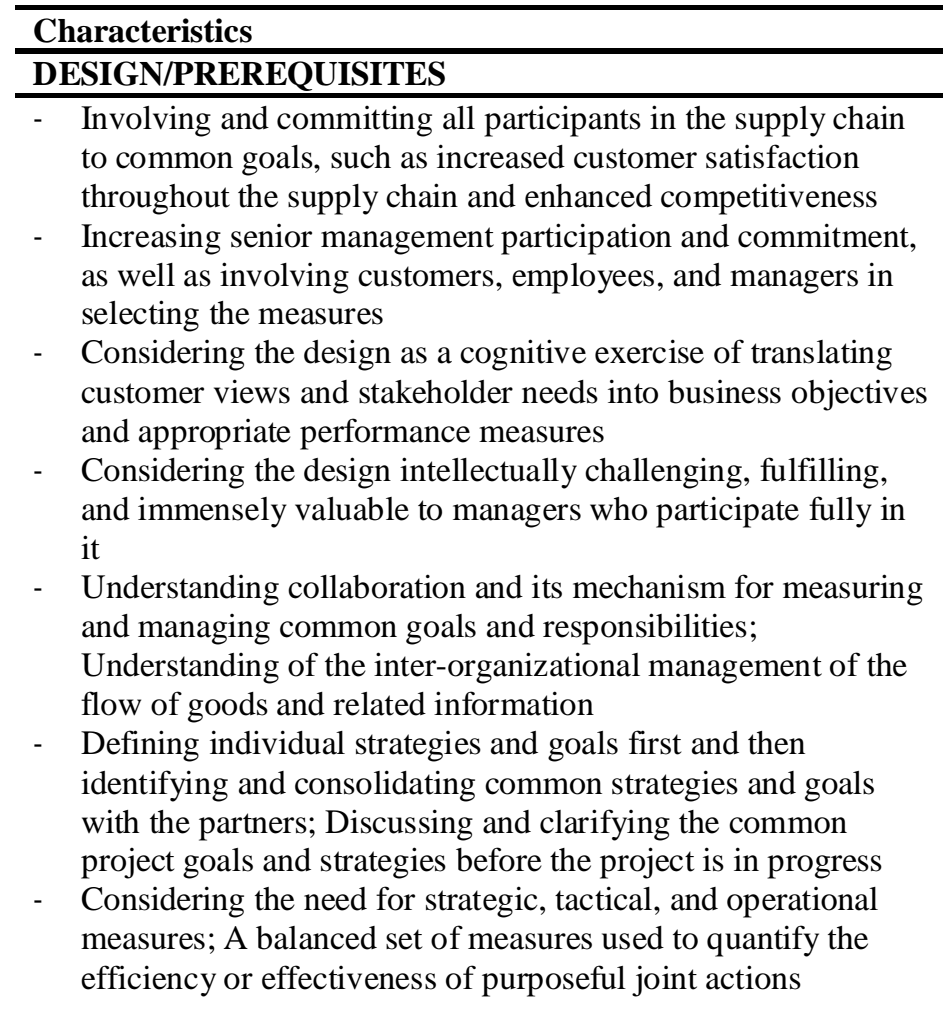

References

Gunasekaran et al., 2004; Hofmann and Locker, 2009

Neely et al., 2000; Kennerley and Neely, 2002; Bourne, 2005; Ukko and Pekkola, 2016

Bourne et al., 2000

Neely et al., 2000

Hofmann and Locker, 2009; Bititci et al., 2012

Niebecker et al., 2010; Ukko et al., 2015

Busi and Bititci, 2006; Papakiriakopoulos and Pramatari, 2010 
- Monitoring external relations and the efficiency of internal and extended processes

- Including measures at different levels to align operations to serve customers in terms of the outcomes the customers desire

\section{DESIGN/CHALLENGES}

- Too many measures and too much focus on financial measures; short-termism and local optimization

- Lack of information about what customers want and how competitors are performing

- Lack of strategic focus or actionable vision and strategy; Difficulty identifying true drivers

- Lack of strategy links to department, team, and individual goals

- Pressure to measure partnership, collaboration, agility, and business excellence requirements

- Difficulty in quantifying future-oriented indicators

- Strategy and measurements are not connected; Too many isolated and incompatible measures in a supply chain

- Collaborations face difficulty evaluating and determining the unit of analysis

\section{IMPLEMENTATION/PREREQUISITES}

- Improving the awareness of a PMS, commitment of senior management, allocation of resources for a PMS, perseverance, and paternalistic culture

- Integrating measurement with strategy development and business process review

- Considering business process management and technical and organizational/managerial issues simultaneously

- Re-evaluating collaboration objectives and re-examining the scope of the collaboration through the incorporation of new business processes

- Assuring an effective communication infrastructure that assists in information sharing, high information quality, and timely information sharing

- Adequate and integrated IT system that links a company with its partners and assists information sharing at the operations level, assists planning and decision-making at the strategy and management levels

- Understanding the importance of collaboration by determining the key elements of the collaboration

- Managing data collaboratively with appropriate information attributes and an interactive information exchange

\section{IMPLEMENTATION/CHALLENGES}

- Encountering fear, company politics, and subversion

- Considering the suppliers and customers opponents rather than partners

- Difficulty developing a collaborative culture and appropriate performance measures

- Effort required for implementation, the personal consequences of measurement, lack of leadership, and resistance to change

- Difficulty accessing data through the IT systems, timeconsuming and costly data collection, inflexible IT systems

- Overlapping projects
Beamon, 1999; Leseure et al., 2001; Busi and Bititci, 2006; Kulmala and Lönnqvist, 2006

Gunasekaran et al., 2004; Hofmann and Locker, 2009; Baines and Lightfoot, 2014

Neely et al., 1995; Neely, 1999;

Schneiderman, 1999; Bourne et al., 2002

Kaplan and Norton 1992; Neely et al., 1995;

Neely, 1999; Kaplan and Norton, 1996

Bierbusse and Siesfeld, 1997;

Schneiderman, 1999; Bourne et al., 2002

Kaplan and Norton, 1996; Bourne et al.,

2002; Ukko et al., 2007

Akyuz and Erkan, 2010

Aramyan et al., 2007

Gunasekaran and Kobu, 2007

Beamon, 1999; Busi and Bititci, 2006

Bourne et al., 2002; Kennerley and Neely, 2002; Bourne, 2005; Charan et al., 2008

Bourne et al., 2002; Kennerley and Neely, 2002; Bourne, 2005

Akyuz and Erkan, 2010

Papakiriakopoulos and Pramatari, 2010

Angerhofer and Angelides, 2006;

Papakiriakopoulos and Pramatari, 2010

Angerhofer and Angelides, 2006; Lu et al., 2006; Papakiriakopoulos and Pramatari, 2010; Liang, 2015

Busi and Bititci, 2006; Papakiriakopoulos and Pramatari, 2010

Henri, 2006; Papakiriakopoulos and Pramatari, 2010; Amir, 2014

Neely et al., 2002

Hofmann and Locker, 2009

Busi and Bititci, 2006

Meekings, 1995; Bourne et al., 2002;

Bourne, 2005

Bierbusse and Siesfeld, 1997; Bourne et al., 2002; Kennerley and Neely, 2002; Bourne, 2005; Nudurupati and Bititci, 2005 Bourne et al., 2000 
The research aims to study the characteristics that are considered crucial to designing and implementing a PMS in an industrial collaboration, in which multiple tiers, extending beyond the buyer-supplier dyad, are considered (cf. Maestrini et al., 2017). We consider prerequisites and challenges crucial characteristics that need to be examined in the design and implementation of a PMS. The research questions are as follows:

RQ1. What are the prerequisites and challenges in the design and implementation of a PMS in an industrial collaboration?

RQ2. How can the prerequisites and challenges be managed in the design and implementation of a PMS in an industrial collaboration?

Regarding RQ1 and RQ2, the empirical results of a PMS design and implementation are discussed and compared against the research framework presented in Table 1. The study aims to provide insights into the research gap related to the characteristics of PMS design and implementation in industrial collaboration with multiple tiers beyond the buyer-supplier dyad.

\section{Methodology}

This article provides insights from two case studies of industrial collaboration. Referring to Yin (2003), one rationale for using case studies is the researcher's access to a situation that was previously inaccessible in the literature; therefore, the descriptive information alone will be revelatory. Because of the nature of the research, the case study was deemed appropriate in terms of the importance of the phenomenon in practice. A case study, which can use various data collection methods, together with a participatory approach to data collection (cf. Maestrini et al., 2016), provides a solid setting for examining the characteristics of PMS design and implementation in industrial collaboration with multiple tiers. In this study, the participatory approach refers to a situation where researchers have assisted the PMS design and implementation process but have not actively participated in decision-making concerning the PMS's content. The research focused on the design and implementation of a PMS and does not examine experiences of using the PMS. Although the design and implementation process was considered successful, 
confirmation of this would have required a more extensive period of investigation. This has been a guideline for this study's research strategy.

\subsection{Case selection}

In Finland, the ongoing global economic transformation is evident in many ways. Due to everincreasing automation, continuous flow production, and fierce competition, the importance of the usability of industrial facilities is emphasized. Thus, industrial services are becoming increasingly important to the global competitiveness of Finnish industries. This shift has provided companies that had engaged purely in production with the opportunity to implement services alongside production activities. Numerous industrial equipment providers have tried to increase their own business by investing in the development of industrial services. A wide base of installed equipment offers a comprehensive foundation for building a service business. However, many equipment providers still adhere to traditional production, and creating support services has been a challenge for these companies. Due to outsourcing, the number of companies that focus solely on industrial services has increased. These industrial service providers can integrate service packages and offer customers comprehensive service agreements and solutions, both regionally and internationally.

Outsourcing industrial services has spread because companies firmly believe that they achieve added value through new kinds of collaborative operating models. In addition, based on previous research, it seems clear that through the systematic development of collaboration between relevant partners, companies can significantly improve the performance and competitiveness of their overall operation (Papakiriakopoulos and Pramatari, 2010; Liang, 2015). Thus, these types of collaborative industrial entities provide a promising research context. The industrial maintenance context was chosen to study a PMS in an industrial collaboration as many of the global trends (such as the digitalization of industry, outsourcing, and a long-term perspective) affect operations. The companies that operate in maintenance collaborations confront increasingly complex and dynamic interactions, in which factories buy maintenance work from their equipment providers or companies specialized in industrial maintenance that sell service agreements or operating services for industrial plants. Many of the actions related to industrial maintenance are critical in terms of the mutual performance of collaboration, as well as business continuity. For this purpose, there is 
a need to study the implementation and design of a PMS, which allows all parties at different tiers of the supply chain to take an active role in the measurement and management process, and enables mutual collaboration in performance. This research area has not been thoroughly investigated thus far (Koufteros et al., 2014; Melnyk et al., 2014; Maestrini et al., 2017; Maestrini et al., 2018).

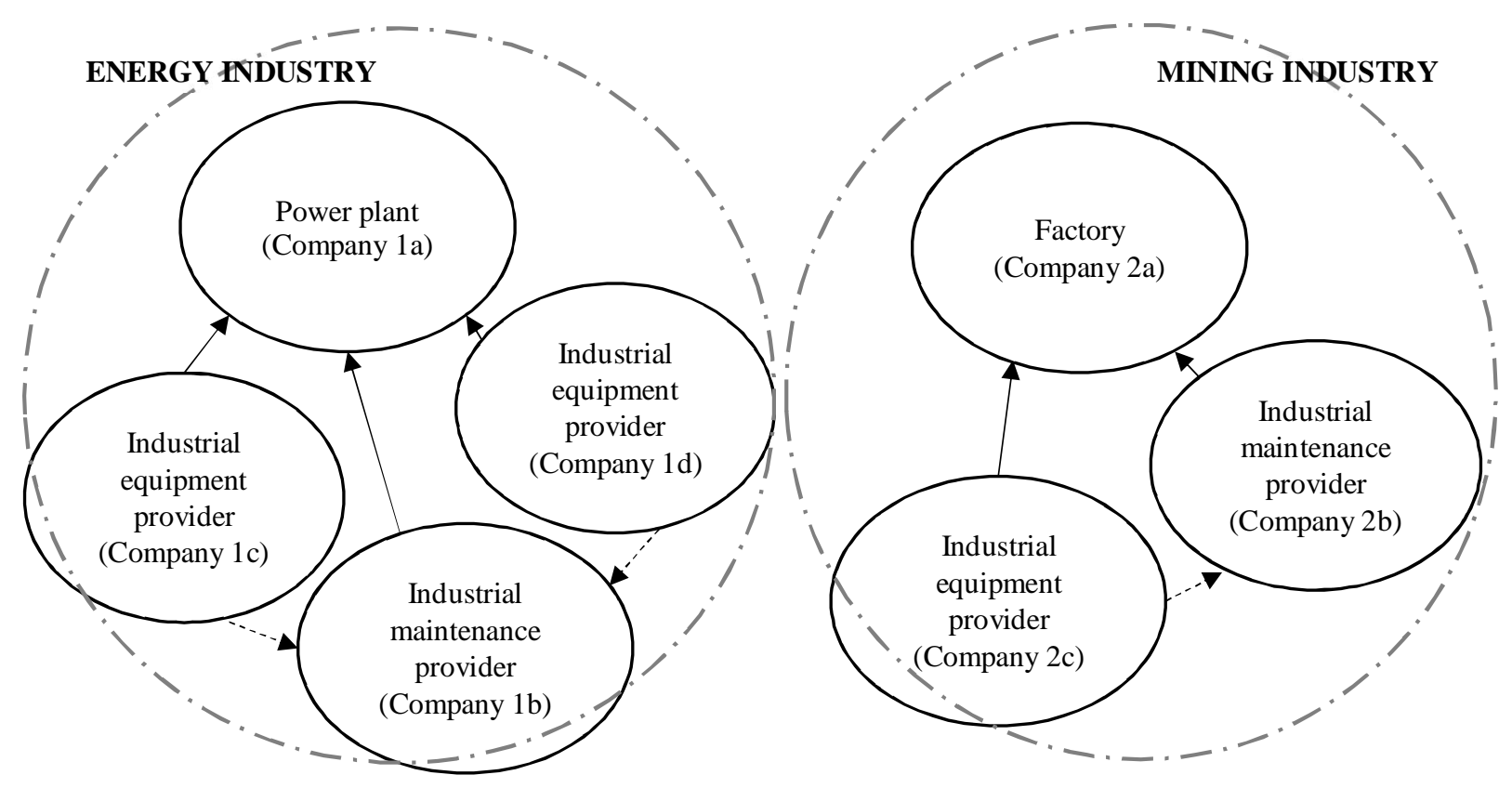

Figure 1. The organization of the companies described in the case studies

Seven companies were used as industrial collaboration cases: four companies in the energy industry and three in the mining industry (Figure 1). Cases were selected based on the level and maturity of industrial collaboration at the companies, because such collaboration plays a crucial role in measuring performance (Busi and Bititci, 2006 Verdecho et al., 2009; Bititci et al., 2012). Therefore, in cases where the need for collaboration is high, it can be reasoned that the design and implementation of PMSs should be emphasized. Furthermore, the cases were chosen from two different industries to analyze prevailing practices across contexts (Yin, 2003). Within each industry, the selected companies played three different roles: as the factory leading the collaboration, as the industrial service provider, and as the industrial equipment provider. The factory collaborates with industrial service providers and with industrial equipment providers. The industrial service provider performs the service in the factory. The industrial equipment provider delivers equipment for the factory's production process. Due to confidentiality, the companies 
were labeled according to their industrial entities. Descriptions of the companies and their relationships, as well as the study participants, are presented in Table 2.

Table 2. Overview of the case companies

\begin{tabular}{|c|c|c|c|}
\hline Company & $\begin{array}{l}\text { Description of the } \\
\text { company }\end{array}$ & $\begin{array}{l}\text { Description of collaboration } \\
\text { between companies }\end{array}$ & Study participants \\
\hline Company 1a & $\begin{array}{l}\text { Company 1a is a factory } \\
\text { that produces electricity } \\
\text { and heat and is a large } \\
\text { Finnish energy } \\
\text { corporation. }\end{array}$ & $\begin{array}{l}\text { Maintenance and operation of the } \\
\text { power plant are outsourced almost } \\
\text { totally to an external service } \\
\text { provider (company } 1 \mathrm{~b} \text { ). Companies } \\
1 \mathrm{c} \text { and } 1 \mathrm{~d} \text { have supplied equipment } \\
\text { to the power plant and are partly } \\
\text { responsible for their maintenance. }\end{array}$ & $\begin{array}{l}\text { Plant Manager, } \\
\text { New Business Development } \\
\text { Manager }\end{array}$ \\
\hline Company $1 \mathrm{~b}$ & $\begin{array}{l}\text { Company } 1 \mathrm{~b} \text { is a large } \\
\text { industrial maintenance } \\
\text { and operations services } \\
\text { provider. }\end{array}$ & $\begin{array}{l}\text { This company runs the operations } \\
\text { and maintenance services of the } \\
\text { power plant of company } 1 \mathrm{a} \text {. It has } \\
\text { purchased equipment from } \\
\text { company } 1 \mathrm{c} \text { and } 1 \mathrm{~d} \text { in order to } \\
\text { provide maintenance to the power } \\
\text { plant. }\end{array}$ & $\begin{array}{l}\text { Head of Expert Services \& } \\
\text { Business Development, } \\
\text { Executive Vice President of } \\
\text { Service Agreements }\end{array}$ \\
\hline Company 1c & $\begin{array}{l}\text { Company } 1 \mathrm{c} \text { is an } \\
\text { industrial equipment } \\
\text { provider whose main } \\
\text { products are industrial } \\
\text { pumps and mixers. }\end{array}$ & $\begin{array}{l}\text { This company has supplied } \\
\text { equipment to company } 1 \mathrm{a} \text { and is } \\
\text { partly responsible for their } \\
\text { maintenance. It is a sub-supplier of } \\
\text { the power plant through company } \\
\text { 1b. }\end{array}$ & $\begin{array}{l}\text { Manager of Service } \\
\text { Business, } \\
\text { Area Sales Manager }\end{array}$ \\
\hline Company 1d & $\begin{array}{l}\text { Company } 1 \mathrm{~d} \text { is an } \\
\text { industrial equipment } \\
\text { provider that produces } \\
\text { and maintains different } \\
\text { types of boilers for } \\
\text { industrial facilities. }\end{array}$ & $\begin{array}{l}\text { This company has supplied } \\
\text { equipment to company } 1 \mathrm{a} \text { and is } \\
\text { partly responsible for their } \\
\text { maintenance. It is a sub-supplier of } \\
\text { the power plant through company } \\
\text { 1b. }\end{array}$ & Business Area Director \\
\hline Company $2 \mathrm{a}$ & $\begin{array}{l}\text { Company } 2 \mathrm{a} \text { is a factory } \\
\text { that produces limestone- } \\
\text { based products for } \\
\text { industry and is part of a } \\
\text { larger international } \\
\text { corporation. }\end{array}$ & $\begin{array}{l}\text { Factory maintenance is outsourced } \\
\text { to company } 2 \text { b. Specialized } \\
\text { maintenance work is supplied by } \\
\text { specialized industrial service } \\
\text { providers. }\end{array}$ & Department Manager, COO \\
\hline Company $2 b$ & $\begin{array}{l}\text { Company } 2 \mathrm{~b} \text { is a small } \\
\text { industrial service } \\
\text { provider with few } \\
\text { customers. }\end{array}$ & $\begin{array}{l}\text { This company operates in close } \\
\text { collaboration with the company } 2 \mathrm{a} \\
\text { factory and takes care of the routine } \\
\text { maintenance of the facilities. It has } \\
\text { purchased equipment from } \\
\text { company } 2 \mathrm{c} \text { in order to provide } \\
\text { maintenance to the factory. }\end{array}$ & $\mathrm{CEO}, \mathrm{COO}$ \\
\hline Company 2c & $\begin{array}{l}\text { Company } 2 \mathrm{c} \text { is a large } \\
\text { industrial equipment } \\
\text { supplier that operates in } \\
\text { the ore, metal, and } \\
\text { energy industries. }\end{array}$ & $\begin{array}{l}\text { This company has supplied } \\
\text { equipment to company } 2 \mathrm{a} \text { and is } \\
\text { partly responsible for their } \\
\text { maintenance. It is a sub-supplier of } \\
\text { the factory through company } 2 \mathrm{~b} \text {. }\end{array}$ & $\begin{array}{l}\text { Manager - Risk } \\
\text { Management, } \\
\text { Manager - Service Business, } \\
\text { Business Area Controller }\end{array}$ \\
\hline
\end{tabular}




\subsection{Data collection and analysis}

To build theory from case studies, detailed observation, triangulation, careful determination of cause-effect chains, and logical inference are required (Meredith, 1998). This guideline was followed throughout the research process. Similar research processes were used for the energy and mining industry cases to ensure scientific transparency and repeatability. The data were gathered between November 2012 and September 2014. The research process included five main phases, in which written assignments, focus groups, and observations were used to collect data. The research phases are presented in Table 3. People from different companies and in different roles participated in the focus groups. To obtain the best possible results for each construct assessed, the participants varied among the focus groups so we could compare viewpoints among companies, as well as among interviewees with various roles regarding industrial collaboration. The data also included written assignments by the representatives of the participating companies, as well as documents and observation diaries from the focus groups. The topics for the focus groups were selected based on the written assignments and an analysis of the previous meeting. Thus, the topics and issues were chosen beforehand (based on the research framework derived from literature), but the discussions were informal and facilitated with supporting questions and comments by the researchers. At the end of the research process, an open-ended survey was utilized to collect additional information. A mix of data collection methods was adopted to increase the validity of the findings. Individual views and opinions of the case company representatives were gathered through pre-assignments before the focus groups and an open-ended survey were conducted at the end of the research process. Focus groups were used as the primary data collection method as they are useful for gathering the opinions of key informants who have a common interest. Focus groups take advantage of group interactions which was considered crucial when studying the characteristics of PMS design and implementation in industrial collaboration.

Researchers conducted the study and then analyzed the data with content analysis (Carley, 1990), after which the researchers discussed the common view. The researchers also adopted theory triangulation. In employing different theoretical frameworks (a PMS in a single organization, supply chains, and industrial collaboration), the goal was to produce new understanding. Although the study belongs to the performance measurement and management research stream, supply chain 
and service management research was also used to integrate existing theory with new contexts. In addition to case-specific analyses, cross-case analyses were conducted. The analyses were conducted at the levels of industrial collaboration and individual organizations. The analysis was informed by the research framework presented in section 2.4. As the goal of the study was not to achieve scientific generalization, theoretical concepts of the research framework were used for themes in the analysis (Yin, 2003). Thus, the data analysis was guided by the prerequisites and challenges of PMS design and implementation presented in the research framework (Table 1).

Table 3. Content of the collected data

\begin{tabular}{|c|c|c|c|c|}
\hline Phase & References & Data gathering & Type of data & Data analysis \\
\hline $\begin{array}{l}\text { Culture and } \\
\text { contextual } \\
\text { factors } \\
\text { Vision and } \\
\text { mission }\end{array}$ & $\begin{array}{l}\text { Bourne et al., } \\
2000,2002 ; \\
\text { Cuthbertson } \\
\text { and } \\
\text { Piotrowicz, } \\
2011 ; \text { Pekkola } \\
\text { and Ukko, } \\
2016\end{array}$ & $\begin{array}{l}\text { Pre-assignment } \\
\text { Focus group ( } 9 \text { participants) } \\
\text { Observations in the focus } \\
\text { group }\end{array}$ & $\begin{array}{l}16 \text { written pre- } \\
\text { assignments } \\
4 \text { written reports of } \\
\text { focus groups } \\
2 \text { observation } \\
\text { diaries }\end{array}$ & $\begin{array}{l}\text { Content analysis of } \\
\text { - written pre- } \\
\text { assignments } \\
\text { - written reports } \\
\text { - observation diaries }\end{array}$ \\
\hline $\begin{array}{l}\text { Organization } \\
\text { structure } \\
\text { Strategies and } \\
\text { plans }\end{array}$ & $\begin{array}{l}\text { Neely, 1999; } \\
\text { Neely et al., } \\
2000 ; \\
\text { Niebecker et } \\
\text { al., } 2010\end{array}$ & $\begin{array}{l}2 \text { focus groups } \\
\text { 1) } 5 \text { participants (from } 4 \\
\text { energy industry companies) } \\
\text { 2) } 3 \text { participants (from } 2 \\
\text { mining industry companies) } \\
\text { Observations in the focus } \\
\text { groups }\end{array}$ & $\begin{array}{l}2 \text { written reports of } \\
\text { focus groups } \\
2 \text { observation } \\
\text { diaries }\end{array}$ & $\begin{array}{l}\text { Content analysis of } \\
\text { - written reports } \\
\text { - observation diaries }\end{array}$ \\
\hline $\begin{array}{l}\text { Key success } \\
\text { factors }\end{array}$ & $\begin{array}{l}\text { Neely et al., } \\
\text { 1995; Neely, } \\
\text { 1999; } \\
\text { Gunasekaran } \\
\text { and Kobu, } \\
2007\end{array}$ & $\begin{array}{l}\text { Pre-assignments } \\
2 \text { focus groups } \\
\text { 1) } 5 \text { participants (from } 4 \\
\text { energy industry companies) } \\
\text { 2) } 3 \text { participants (from } 2 \\
\text { mining industry companies) } \\
\text { Observations in the focus } \\
\text { groups }\end{array}$ & $\begin{array}{l}\text { written pre- } \\
\text { assignments } \\
2 \text { written reports of } \\
\text { focus groups } \\
2 \text { observation } \\
\text { diaries }\end{array}$ & $\begin{array}{l}\text { Content analysis of } \\
\text { - written pre- } \\
\text { assignments } \\
\text { - written reports } \\
\text { - observation diaries }\end{array}$ \\
\hline $\begin{array}{l}\text { Key } \\
\text { performance } \\
\text { measures } \\
\text { Target setting }\end{array}$ & $\begin{array}{l}\text { Neely et al., } \\
\text { 1995; Neely, } \\
1999 ; \\
\text { Gunasekaran } \\
\text { and Kobu, } \\
2007\end{array}$ & $\begin{array}{l}2 \text { focus groups } \\
\text { 1) } 4 \text { participants (from } 3 \\
\text { energy industry companies) } \\
\text { 2) } 3 \text { participants (from } 3 \\
\text { mining industry companies) } \\
\text { Observations in the focus } \\
\text { groups }\end{array}$ & $\begin{array}{l}2 \text { written reports of } \\
\text { focus groups } \\
2 \text { observation } \\
\text { diaries }\end{array}$ & $\begin{array}{l}\text { Content analysis of } \\
\text { - written reports } \\
\text { - observation diaries }\end{array}$ \\
\hline $\begin{array}{l}\text { Performance } \\
\text { evaluation } \\
\text { Implementation }\end{array}$ & $\begin{array}{l}\text { Bourne et al., } \\
\text { 2000, 2002; } \\
\text { Busi and } \\
\text { Bititci, 2006; } \\
\text { Parung and } \\
\text { Bititci, 2008 } \\
\end{array}$ & $\begin{array}{l}\text { Focus group (6 participants) } \\
\text { Observations in the focus } \\
\text { group } \\
\text { Open-ended survey }\end{array}$ & $\begin{array}{l}1 \text { written report of } \\
\text { focus group } \\
1 \text { observation diary } \\
\text { Written survey } \\
\text { responses }\end{array}$ & $\begin{array}{l}\text { Content analysis of } \\
\text { - written report } \\
\text { - observation diary } \\
\text { - open-ended survey } \\
\text { responses }\end{array}$ \\
\hline
\end{tabular}




\section{Results}

In this section, the prerequisites and challenges of designing and implementing a PMS for industrial collaboration are presented and analyzed. Table 4 presents the main features of the PMSs in the investigated industrial collaborations.

Table 4. Main features of the PMSs

\begin{tabular}{|c|c|c|}
\hline & Energy case & Mining case \\
\hline $\begin{array}{l}\text { How the PMS was } \\
\text { designed and } \\
\text { implemented }\end{array}$ & $\begin{array}{l}\text { Designed collaboratively during focus } \\
\text { groups, Implemented under the } \\
\text { leadership of the power plant and the } \\
\text { industrial maintenance provider }\end{array}$ & $\begin{array}{l}\text { Designed collaboratively during focus } \\
\text { groups, Implemented under the leadership } \\
\text { of the factory and the industrial } \\
\text { maintenance provider }\end{array}$ \\
\hline Who designed the PMS & $\begin{array}{l}\text { Collaboratively between industrial entity } \\
\text { members }\end{array}$ & $\begin{array}{l}\text { Collaboratively between industrial entity } \\
\text { members }\end{array}$ \\
\hline $\begin{array}{l}\text { What type of KPIs } \\
\text { were included }\end{array}$ & $\begin{array}{l}\text { Safety (compliance with work safety } \\
\text { policies, compliance with environmental } \\
\text { safety policies, recycling of materials) } \\
\text { Quality (provider reviews, reputation, } \\
\text { know-how, energy efficiency, } \\
\text { predictive/corrective maintenance } \\
\text { service) } \\
\text { Reliability (timely execution of the } \\
\text { maintenance work, timely deliveries, } \\
\text { flexibility in hurdles, speed and quality } \\
\text { of service, compliance of the } \\
\text { maintenance work as promised, } \\
\text { functioning of the target of the } \\
\text { maintenance work) } \\
\text { Cooperation (contract duration, } \\
\text { management commitment) } \\
\text { Finances (costs, price compared to the } \\
\text { received service) } \\
\text { Customer value/satisfaction }\end{array}$ & $\begin{array}{l}\text { Safety (compliance with work safety } \\
\text { policies, compliance with environmental } \\
\text { safety policies) } \\
\text { Quality (maintenance outcome compared } \\
\text { to planned and agreement, maintenance } \\
\text { outcome is sustained for the promised } \\
\text { time, information provision related to } \\
\text { equipment/production process) } \\
\text { Reliability (timely execution of the } \\
\text { maintenance work, compliance of the } \\
\text { maintenance work as promised, } \\
\text { functioning of the target of the } \\
\text { maintenance work, reclamations) } \\
\text { Cooperation (information exchange, } \\
\text { compliance of agreement (service warranty } \\
\text { and terms of payment), service attitude) } \\
\text { Finances (costs, price compared to the } \\
\text { received service) } \\
\text { Customer value/satisfaction }\end{array}$ \\
\hline Who manages the PMS & Under the leadership of the power plant & Under the leadership of the factory \\
\hline $\begin{array}{l}\text { Who collects data and } \\
\text { calculates the KPIs }\end{array}$ & $\begin{array}{l}\text { Power plant as responsible, Each } \\
\text { company on its own perspective }\end{array}$ & $\begin{array}{l}\text { Factory as responsible, Each company on } \\
\text { its own perspective }\end{array}$ \\
\hline $\begin{array}{l}\text { How is information } \\
\text { shared among the } \\
\text { partners }\end{array}$ & $\begin{array}{l}\text { Collaboratively formed action plan for } \\
\text { the next year, shared with partners } \\
\text { Meetings in which actions are reviewed } \\
\text { (are actions working as planned, are } \\
\text { costs within budget, etc.) }\end{array}$ & $\begin{array}{l}\text { Informal meeting once a year, Discussions } \\
\text { as soon as problems occur } \\
\text { (verbally but also documented and shared } \\
\text { with the partner) }\end{array}$ \\
\hline
\end{tabular}

\subsection{Prerequisites for PMS design in industrial collaboration}

When focusing on the design of a PMS in an industrial collaboration, the various actors and their roles in the industrial entity must be defined. In an energy case, the main actor provides services 
and products to the end customer (in this case, end customer refers to the consumer or company that buys electricity from the plant) and to the other actors in the value chain that provide services and equipment to the main actor. Throughout the research process, it became apparent that the strategic alignment of the whole entity was considered important, including responsibilities within the entity. The roles and responsibilities of the different actors need to be defined, because to benefit a PMS within the context of industrial collaboration a systematic approach to the management of the industrial entity was required. A focus group participant from the energy case stated the importance of clearly defined responsibilities:

Who will lead this [collaborative] entity? In this way, it is possible to get the individual actors to really work together to achieve the same common goal.

A systematic approach to managing the entire entity [is needed] in order to see how the whole [entity] works and focus on improving the right things.

This requires bringing partners together to discuss and clarify their common strategies and project goals before the PMS project is in progress. From the viewpoint of the design phase of performance measurement, the maturity of the collaboration is sufficient only when the collaboration between the actors is considered strategic. For the collaboration to be considered strategic, the collaborative entity needs a mutual vision, strategy, and targets. The PMS design process, which was conducted during the focus group meetings, was considered one means of deepening the collaboration and increasing the motivation to work toward a common goal and communication within the industrial entity.

With respect to roles and responsibilities, the dynamics of the collaboration were considered to play a big role in designing the PMS. Thus, the development of a collaborative culture was perceived to be important in the case study collaborations. This type of culture could increase the flexibility of the collaboration, but it was also considered highly dependent on the individual PMS project participants. In the focus group discussions, trust between the actors, as well as the continuity of the collaboration, was perceived as crucial during the design phase.

Another prerequisite for collaborative PMS design is the specification of the total value of the collaboration, which was highlighted in both cases. Specification includes identifying the value 
elements and how they should be managed. During the focus groups, the participants agreed that shared processes and resources should be more efficient and that the processes of other actors within the entity should also be better understood. The collaborative partners need to operate together as a unit—not as separate actors with individual targets. Operating together requires seeking mutual benefit and commitment from all partners involved. Within the mining entity, the main reason for developing a measurement for the collaborative performance was to better manage the end customer (in this case, end customer refers to a company that buys the plant's products) interface. The end customers wanted to do business through one specified contact. Further, the main characteristics for the performance measurement of a mining entity was connected to the vast variety of end customers. The common opinion was that before measurement is implemented, customers need to be segmented to offer targeted services depending, for example, on how critical the service is for the customer. Because different customer segments found different issues in service delivery to be important, different measures for each customer segment were needed. The need to consider the end customer interface was highlighted in the comment of a mining company manager: "Different issues are important to different segments-thus, different measures depending on the criticality of the process."

When focusing on the performance measurement of industrial collaboration, developing a measurement that covers the nested processes of different actors within the collaboration and the individual processes within the entire entity is necessary. In this way, it is possible to simultaneously measure the extended processes of the industrial entity and to ensure their effectiveness. Traditionally, the case study organizations measured their own practices as part of their extended processes for industrial collaboration. However, this approach eventually led to discontinuities and a situation in which the different partners' processes were measured separately. The focus group participants agreed that the processes of the individual actors must have their own measures, which should be linked to the measures for the entire entity. This approach can be advanced by utilizing strategy maps. The results for the measures related to the individual actors' processes should be in line with the results for the measures for the entire entity and its extended processes. The focus group participants from both cases acknowledged the importance of linking these measures to the strategy-level measures of the individual companies. Managers from the 
energy companies, who participated in the focus groups, clarified the role of the different types of measurement as follows:

Upper-level targets and measures must be defined first ... and then the measures for individual actors. Monitoring from individual teams to the entire entity must be able to trace the link from the bottom up.

There are two types of measures: key measures and supportive measures that act as an input for the key measures ... Measures must be able to be changed according to the situation.

\subsection{Prerequisites for PMS implementation in industrial collaboration}

Integrating processes of the industrial entity is necessary during the design phase, which is similar to integrating information systems during the implementation phase. Strategic collaboration requires that individual organizations' processes be integrated with those of the other organizations. A collaborative entity, such as the case study entities, includes clearly defined extended processes, common information systems, and the information systems of individual partners. Synchronization of these systems and data transmission are necessary in order to measure and manage the integrated processes of the entire entity. In the case industrial entities, the definition and a shared understanding of common rules for measuring and managing an industrial entity with the commitment of all organizational levels were considered important. The role of information systems in building this understanding was stated by the manager of the energy case: "[One must] take into account the common systems throughout the [collaborative] entity: systems managed by different parties, synchronization systems, and data transmission."

Among the mining companies, the implementation process of a collaboration-level PMS was considered as important as the measurement itself. The PMS must be implemented at different organizational levels. The measurement of the mutual processes of the different organizational levels should be systematic, and the decisions must be based on the measurement information. Lack of understanding of the purpose of the measurement at a different organizational level of an industrial entity may lead to unsuccessful utilization of the measurement. This type of behavior is difficult to change afterward. The department manager of a company operating in the mining case 
company stated: "If you cannot explain to staff why and for what it [the measurement] is used, it can lead to poor provision of data; poor provision of data is more useless than no data at all."

The guiding effect of the PMS was highlighted in both cases. During the implementation phase, critically assessing that the right measures have been selected and ensuring that these measures are actively used to manage the collaboration are necessary. The focus group discussions highlighted that one of the actors must be responsible for managing and measuring the level of industrial collaboration. This was viewed as a means of ensuring the continuity and increasing the manageability of the collaboration. The focus groups concluded that the measures should be changed when necessary (e.g., when the collaboration develops).

The actors in the industrial collaboration believed that the measurement would solve many problems in service production. The proper PMS would increase collaboration and communication among the different actors. Discussion about the measurement information can take place before, during, and after the service is delivered. The PMS enables mutual targets, which, in turn, helps with the development of rules concerning the actions of different actors in the industrial entity. The importance of mutual understanding of the terms of collaboration and the role of measurement in collaboration was clarified by a mining representative: "The supplier and the client must be more in co-operation than currently is [the case]; that means discussing before, during, and after the work is done."

\subsection{Challenges of PMS design in industrial collaboration}

The main challenges concerning the PMS design of an industrial collaboration are linked to understanding the level of collaboration. The common opinion was that the collaboration between the actors was strategic and that this direction would continue. The main issue concerning the collaboration was the level of integration of the processes of different actors. If the processes of different actors were not integrated with other actors within an entity and its processes, seeing the strategic elements of the industrial collaboration became difficult. 
Through the collaboration-level vision and targets, it is possible to define the value provided by different actors. However, this definition is not sufficient without a clear determination of the roles and responsibilities of different actors. It was stated that one of the actors must play an instrumental role in managing and measuring an instance of industrial collaboration. Even if the strategy and processes of an industrial entity are defined and are in line with those of the upper-level actors, the major challenge is to transmit the same understanding and thinking to the operations level of the entity. A significant amount of openness is needed when calculating, for example, the costs and benefits of the actors' integrated processes. Openness can be advanced by creating proper information channels for communicating mutual benefits and targets. An energy company manager stated:

Functionality requires a commitment of each member [of the industrial entity]; each cannot think of just one's own margin, but rather a common benefit, something for everyone.

[This] requires internalizing the ways of action and commitment in all organizations and at all levels of the organizations.

\subsection{Challenges of PMS implementation in industrial collaboration}

Regarding PMS implementation, it is important to systematically measure the mutual extended processes of the entity's different organizational levels. In the study, a common perception among the actors was that the decisions should be based on collaboration-level measurement information in order to understand the decisions and the results. The challenge is that many actors also use several measures for their own businesses, and there is a risk of confusing these measures with the collaboration-level measures. The challenge for managers lies in ensuring that individual actors' measures are in line with the collaboration-level measures. The challenge of implementing proper measures for different phases and purposes was highlighted by an energy company participant: "The most important thing is to choose the right measures/dimensions and then to ensure their active management." "Follow-up is the most critical phase; this ensures that the measures are correct and develop better." In this regard, integrating information systems and developing data were considered challenging. Thus, integrating information systems requires collaboration throughout the industrial entity at the strategic level, and mutual benefits must be clearly defined. 
Although interlinked processes was one of the key themes in the focus groups on PMS design, the reflections of the last focus group and its open-ended survey confirmed that interlinked processes, with respect to information system integration and process coordination, determine the success of the implementation phase. To be truly beneficial for all actors involved in an industrial collaboration, integrating the information systems and data development thoroughly is vital.

The results also indicate that the implementation process of a PMS is challenging when the entity needs to deliver different value elements through services depending on the type of customer. Thus, the variety of services conducted for customers was considered one of the main challenges of implementing a PMS. The different customer services included different value elements. This means the actors in an industrial entity also provided different additional value for the different service processes. This was seen as a challenge because the measures of the service processes for a certain customer segment must be implemented separately, as one part of the PMS of an entire entity.

\subsection{Cross-case analysis and summary of the results}

In this section, the prerequisites and challenges of PMS design and implementation in industrial collaboration are presented, and then the perceived differences are identified and analyzed. A summary of the main findings is presented in Table 5. The results emerged through three major themes, which have been titled as key characteristics in Table 5. Based on the analysis, three central issues characterize the design and implementation of a PMS in the context of industrial collaboration: 1) the importance of collaboration, 2) the importance of coordination and integrated information systems within the system implementation, and 3) the importance of acknowledging the impact of varied customer needs. These characteristics can be considered prerequisites or challenges, and they contain aspects that have been explored and grouped in accordance with the research framework presented in Section 2.4 (design and implementation). Although many of the characteristics of the design and implementation phases overlap, the emphasized phase is noted in the table. These characteristics will be briefly introduced here and discussed in relation to previous studies and in relation to the research framework in the discussion and conclusions section. 
Table 5. Summary of the results

\begin{tabular}{|c|c|c|}
\hline \multirow{2}{*}{$\begin{array}{l}\text { Key } \\
\text { characteristics }\end{array}$} & \multicolumn{2}{|l|}{ Aspects illuminated } \\
\hline & Design & Implementation \\
\hline $\begin{array}{l}\text { Importance of } \\
\text { collaboration }\end{array}$ & $\begin{array}{l}\text { Better management of the end- } \\
\text { customer interface } \\
-\quad \text { This is the main purpose of } \\
\text { collaboration } \\
\text { Strategic alignment for collaboration } \\
-\quad \text { A systematic approach for } \\
\text { management that involves the } \\
\text { commitment of senior } \\
\text { management and } \\
\text { responsibilities } \\
\text { Worth effort } \\
\text { - The total value of the } \\
\text { collaboration versus the } \\
\text { contribution of each partner is } \\
\text { calculated }\end{array}$ & $\begin{array}{l}\text { Collaboration culture } \\
-\quad \text { Collaboration operators are viewed as real } \\
\quad \text { partners rather than opponents }\end{array}$ \\
\hline $\begin{array}{l}\text { Importance of } \\
\text { process } \\
\text { coordination } \\
\text { and ICT } \\
\text { systems- } \\
\text { integration } \\
\text { within the } \\
\text { system } \\
\text { implementation }\end{array}$ & $\begin{array}{l}\text { Definition of extended processes } \\
\text { - } \quad \text { A full understanding of which } \\
\text { processes are involved in the } \\
\text { collaboration and which are } \\
\text { not }\end{array}$ & $\begin{array}{l}\text { Awareness of the collaborative PMS } \\
\text { - } \quad \text { Informing different organizational levels } \\
\text { about the extended processes and the new } \\
\text { PMS } \\
\text { Implementation of extended processes } \\
\text { - } \quad \text { Is as important as performance } \\
\text { measurement } \\
\text { - } \quad \begin{array}{l}\text { Needs to be implemented before the } \\
\text { measurement efforts are implemented }\end{array} \\
\text { Discussion about the extended processes and } \\
\text { measurement information } \\
\text { - } \quad \text { Should be carried out before, during, and } \\
\text { after the service is delivered } \\
\text { - } \quad \begin{array}{l}\text { Focus on business improvement rather } \\
\text { than performance measurement }\end{array} \\
\text { - Integrate information systems after } \\
\text { considering the extended processes } \\
\text { - Without the common information system, } \\
\text { the benefits of the extended processes will } \\
\text { not be achieved }\end{array}$ \\
\hline $\begin{array}{l}\text { Importance of } \\
\text { acknowledging } \\
\text { the impact of } \\
\text { customer needs } \\
\text { in terms of } \\
\text { variety }\end{array}$ & $\begin{array}{l}\text { Customer segmentation } \\
\text { - } \quad \text { The variety of customers } \\
\text { affects the design of a PMS } \\
\text { - } \quad \text { Different measures should be } \\
\text { implemented for different } \\
\text { customers } \\
\text { - } \quad \text { Value provided by different } \\
\text { partners depends on the } \\
\text { customer segment }\end{array}$ & $\begin{array}{l}\text { Customer involvement in performance } \\
\text { measurement } \\
\text { - } \quad \text { Providing information about their } \\
\text { operating environment } \\
\text { - } \quad \begin{array}{l}\text { Being critical of the delivered service and } \\
\text { product }\end{array}\end{array}$ \\
\hline
\end{tabular}

With respect to the design phase, the PMS for an industrial collaboration case with multiple actors was considered to be too convoluted without strategic collaboration. Without a clear vision and targets for co-operation, integrating the service processes and information systems was considered 
too laborious and expensive. For this reason, bringing partners together to discuss and clarify their common strategies and project goals before the project is in progress was perceived as very important.

Furthermore, regarding the implementation phase, it was perceived that, without the integration of processes and information systems, the measurement of industrial collaboration would be too shallow and would not correspond to its purpose. To better manage this integration, the development of a collaborative culture was perceived to be significant in the case study collaborations, especially during the implementation phase. During this phase, the importance of understanding the impact of customer needs in terms of their variety was also perceived as crucial. This means, for example, acknowledging how critical a delivered service or product is to a specific customer.

The primary difference between the energy and mining collaborations was the nature of the customer companies. For instance, the energy entity had more homogenous customers, while the mining entity had customers with various needs for various services. This factor was realized in the form of various measures for the different customers within the mining entity's collaboration. As a result, the PMS must be implemented more thoroughly throughout the various organizational levels of an industrial collaboration. In the study, the value provided by different actors within the mining collaboration also depended on the type of customer. In addition, the value provided by an individual actor could change, depending on the type of customer. In the energy collaboration, the value provided by the actors for certain service processes was more stable, regardless of the type of customer.

\section{Discussion and conclusions}

This study focused on the research gap in the design and implementation of a PMS for industrial collaboration. The setting is a multitier collaboration, where all parties intend to take an active role in the measurement and management process and enable mutual collaboration in performance. This study provides several contributions to SCM literature. It deals with the management of industrial collaboration and, more specifically, the design and implementation of a PMS for 
industrial collaboration, in which multiple tiers, extending beyond the buyer-supplier dyad, are considered. Specifically, the study provides novel results regarding (1) the current limitations of literature focused on the PMS design phase by identifying the crucial characteristics that should be examined in both the design and implementation of a PMS, and (2) the lack of an empirical analysis by considering multiple tiers, extending beyond the buyer-supplier dyad, and configuring a multitier SCPMS.

\subsection{Theoretical implications}

As the primary contribution to this field of study, three main factors that characterize the design and implementation of a PMS in an industrial-collaboration context emerged: 1) the importance of collaboration, 2) the importance of coordinated and integrated information systems within the system implementation, and 3) the importance of acknowledging the impact of varied customer needs.

First, PMS design and implementation need a strong collaborative relationship, beyond the buyersupplier dyad. The study reveals that PMS design and implementation need to target the management of the end-customer interface. Thus, the results contribute to the neglected topic of multitier collaboration (Maestrini et al., 2017). The necessary level of collaboration is realized by building a strategic-alignment process for collaboration (Niebecker et al., 2010; Ukko et al., 2015) and building value for each partner beyond that of invested resources (Camarinha-Matos et al., 2009; Bititci et al., 2012). Collaborative culture is required in the design and implementation of a PMS (Busi and Bititci, 2006); a PMS in itself does not provide adequate, mutual benefit for industrial collaboration. The design, implementation, and further use create value. Gaining this advantage throughout the process requires the collaboration to be among multiple tiers and at an appropriate level.

Second, industrial collaboration needs a rigorous coordination of processes and integrations of ICT systems in order for PMS design and implementation to succeed. This means defining and understanding the processes that are involved in the collaboration, as well as implementing these processes (Angerhofer and Angelides, 2006; Hofmann and Locker, 2009). PMS implementation 
in an industrial-collaboration context requires considerations of business process-management and managerial and technical issues (Akyuz and Erkan, 2010). In addition to business-process management, data management is also crucial (Papakiriakopoulos and Pramatari, 2010). Thus, the study strongly supports the view that ICT systems are especially important in a collaborative PMS, as they link a company to its partners and provide an effective communication infrastructure by assisting in the sharing of information (Angerhofer and Angelides, 2006; Lu et al., 2006; Papakiriakopoulos and Pramatari, 2010; Liang, 2015). This also promotes the awareness of the collaborative nature of PMS implementation, perceived as crucial among the actors in different tiers of the supply chain (Charan et al., 2008).

Third, in the design and implementation of a PMS for industrial collaboration, acknowledging the impact of various customer needs is crucial: Performance measures that reflect outcomes aligned to individual customers must be adopted, and these performance measures should then be used in the extended processes of different organizations (Baines and Lightfoot, 2014). This indicates that customers need to be segmented so that companies can offer targeted services, depending, for example, on how critical the service is for the customer (Pohl and Förstl, 2011; Ukko and Pekkola, 2016). Measures within the different tiers of industrial collaboration are required in order to align operations and serve customers in terms of the desired outcomes of the customers (Gunasekaran et al., 2004; Hofmann and Locker, 2009; Baines and Lightfoot, 2014). For these measures to be implemented, information about customers' operating environments, their specific needs and desires, as well as their participation in evaluating the delivered products and services, are required (Neely et al., 2000; Kennerley and Neely, 2002; Bititci et al., 2012; Ukko and Pekkola, 2016).

\subsection{Managerial implications}

In terms of managerial implications, the study results suggest that actors in industrial collaborations should carefully consider the state of the collaboration before starting the design process for the PMS. It is important to spread awareness of the end-customer interface across multiple supply-chain tiers and discuss shared measures between different tiers with regard to the end customer. Defining common goals and extended processes and developing compatible information systems are essential to provide a solid foundation for developing the PMS. In 
addition, the case examples described here can help practitioners avoid pitfalls when designing and implementing a PMS in a multitier industrial supply chain. The study results assist practitioners in this task by showing what factors are emphasized in an industrial collaboration that seeks mutual collaboration in performance.

\subsection{Limitations and future research}

As a limitation, the findings of this study are based on data from only two cases, which limits the manner in which the results might be generalized. However, due to the nature of the research subject, an in-depth case study is an appropriate research strategy for gaining a deeper understanding of the design and implementation of a PMS for industrial collaboration. This study showed that more in-depth action research and case studies are needed to validate the results in terms of suitability, usefulness, and acceptability. There are other potential limitations concerning the data collection methods, as well as those usually associated with case studies. To minimize these issues, four researchers gathered the data and analyzed them using content analysis, after which the common view was discussed. Theory triangulation was also adopted. By employing different theoretical frameworks, the goal was to produce new understandings.

Concerning future research, more case studies on different types of industrial collaboration should be conducted to generalize the findings. For example, an understanding of what elements are emphasized in a successful design and implementation process for a PMS for different types of industrial collaboration would be beneficial for academics and practitioners. It is also essential to study measures that have been successfully implemented in practice.

\section{References}

Akyuz, A.G. and Erkan, E.T. (2010) Supply chain performance measurement: a literature review, International Journal of Production Research, Vol. 48, No. 17, pp. 5137-5155.

Amir, A.M. (2014) Performance measurement system design in service operations, Management Research Review, Vol. 37, No. 8, pp. 728-749.

Angerhofer, B.J. and Angelides, M.C. (2006) A model and a performance measurement system for collaborative supply chains, Decision Support Systems, Vol. 42, No. 1, pp. 283-301. 
Aramyan, L.H., Oude Lansink, A.G., Van Der Vorst, J.G. and Van Kooten, O. (2007) Performance measurement in agri-food supply chains: a case study, Supply Chain Management: An International Journal, Vol. 12, No. 4, pp. 304-315.

Baines, T. and Lightfoot, H.W. (2014) Servitization of the manufacturing firm: Exploring the operations practices and technologies that deliver advanced services, International Journal of Operations \& Production Management, Vol. 34, No. 1, pp. 2-35.

Beamon, B.M. (1999) Measuring supply chain performance, International Journal of Operations \& Production Management, Vol. 19, No. 3, pp. 275-292.

Bierbusse, P. and Siesfeld, T. (1997) Measures that matter, Journal of Strategic Performance Measurement, Vol. 1, No. 2, pp. 6-11.

Bititci, U.S., Martinez, M., Albores, P. and Parung, J. (2004) Creating and managing value in collaborative network, International Journal of Physical Distribution \& Logistics Management, Vol. 34, No. 3, pp. 251-268.

Bititci, U.S., Garengo, P., Dörfler, V. and Nudurupati, S. (2012) Performance measurement: challenges for tomorrow, International Journal of Management Reviews, Vol. 14, No. 3, pp. 305327.

Bititci, U., Turner, T., Mackay, D., Kearney, D., Parung, J. and Walters, D. (2007) Managing synergy in collaborative enterprises, Production Planning \& Control, Vol. 6, No. 18, pp. 454-465.

Bourne, M. (2005) Researching performance measurement system implementation: the dynamics of success and failure, Production Planning \& Control, Vol.16, No. 2, pp. 101-113.

Bourne, M., Mills, J., Wilcox, M., Neely, A. and Platts, K. (2000) Designing, implementing and updating performance measurement systems, International Journal of Operations \& Production Management, Vol. 20, No. 7, pp. 754-771.

Bourne, M., Neely, A., Platts, K. and Mills, J. (2002) The success and failure of performance measurement initiatives. Perceptions of participating managers, International Journal of Operations \& Production Management, Vol. 22, No. 11, pp. 1288-1310.

Busi, M. and Bititci, U.S. (2006) Collaborative performance management: present gaps and future research, International Journal of Productivity and Performance Management, Vol. 55, No. 1, pp. $7-25$.

Camarinha-Matos, L.M., Afsarmanesh, H., Galeano, N. and Molina, A. (2009) Collaborative networked organizations - concepts and practice in manufacturing enterprises, Computers \& Industrial Engineering, Vol. 57, No. 1, pp. 46-60.

Cavalieri, S., and Pezzotta, G. (2012) Product-Service Systems Engineering: State of the art and research challenges, Computers in Industry, Vol. 63 No. 4, pp. 278-288.

Chan, F.T. (2003) Performance measurement in a supply chain, The International Journal of Advanced Manufacturing Technology, Vol. 21, No. 7, pp. 534-548. 
Charan, P., Shankar, R. and Baisya, R.K. (2008) Analysis of interactions among the variables of supply chain performance measurement system implementation, Business Process Management Journal, Vol. 14, No. 4, pp. 512-529.

Chelariu, C., Kwame Asare, A. and Brashear-Alejandro, T. (2014) "A ROSE, by any other name"...: relationship typology and performance measurement in supply chains, Journal of Business \& Industrial Marketing, Vol. 29, No. 4, pp. 332-343.

Cuthbertson, R. and Piotrowicz, W. (2011) Performance measurement systems in supply chains: a framework for contextual analysis, International Journal of Productivity and Performance Management, Vol. 60, No. 6, pp. 583-602.

Gunasekaran, A. and Kobu, B. (2007) Performance measures and metrics in logistics and supply chain management: a review of recent literature (1995-2004) for research and applications, International Journal of Production Research, Vol. 45, No. 12, pp. 2819-2840.

Gunasekaran, A., Patel, C. and McGaughey, R.E. (2004) A framework for supply chain performance measurement, International Journal of Production Economics, Vol. 87, No. 3, pp. 333-347.

Gunasekaran, A., Patel, C. and Tirtiroglu, E. (2001) Performance measures and metrics in a supply chain environment, International Journal of Operations \& Production Management, Vol. 21, Nos. 1/2, pp. 71-87.

Henri, J. (2006) Management control systems and strategy: a resource-based perspective, Accounting, Organizations and Society, Vol. 31 No. 6, pp. 529-558.

Hofmann, E. and Locker, A. (2009) Value-based performance measurement in supply chains: a case study from the packaging industry, Production Planning and Control, Vol. 20, No. 1, pp. 6881 .

Huxham, C. (Ed.) (1996) Creating Collaborative Advantage, Sage Publications, London.

Håkansson, H. and Lind, J. (2004) Accounting and network coordination, Accounting, Organizations and Society, Vol. 29, No. 1, pp. 51-72.

Kald, M. and Nilsson, F. (2000) Performance measurement at Nordic companies, European Management Journal, Vol. 18, No. 1, pp. 113-127.

Kaplan, R.S. and Norton, D.P. (1992) The Balanced Scorecard: measures that drive performance, Harvard Business Review, Vol. 70, No. 1, pp. 71-79.

Kaplan, R.S. and Norton, D.P. (1996) The Balanced Scorecard: Translating Strategy into Action, Harvard Business School Press, Boston, MA.

Kaplan, R.S., Norton, D.P. and Rugelsjoen, B. (2010) Managing alliances with the balanced scorecard, Harvard Business Review, Vol. 88, No. 1, pp. 68-75.

Kennerley, M. and Neely, A. (2002) A framework of the factors affecting the evolution of performance measurement systems, International Journal of Operations \& Production Management, Vol. 22, No. 11, pp. 1222-1245. 
Koufteros, X., Verghese, A.J. and Lucianetti, L. (2014) The effect of performance measurement systems on firm performance: A cross-sectional and a longitudinal study, Journal of Operations Management, Vol. 32, No. 6, pp. 313-336.

Kovács, G. and Spens, K.M. (2005) Abductive reasoning in logistics research, International Journal of Physical Distribution \& Logistics Management, Vol. 35, No. 2, pp. 132-144.

Kulmala, H.I. and Lönnqvist, A. (2006) Performance measurement of networks: towards a nonfinancial approach, International Journal of Networking and Virtual Organizations, Vol. 3, No. 3, pp. 299-316.

Leseure, M., Shaw, N. and Chapman, G. (2001) Performance measurement in organizational networks: an exploratory case study, International Journal of Business Performance Management, Vol. 3, No. 1, pp. 30-46.

Liang, Y.H. (2015) Performance measurement of interorganizational information systems in the supply chain, International Journal of Production Research, Vol. 53, No. 18, pp. 5484-5499.

Lovelock, C. and Gummesson, E. (2004) Wither service marketing? In search of new paradigm and fresh perspectives, Journal of Service Research, Vol. 47, pp. 9-20.

Lu, X.H., Huang, L.H. and Heng, M.S. (2006) Critical success factors of inter-organizational information systems-A case study of Cisco and Xiao Tong in China, Information \& management, Vol. 43, No. 3, pp. 395-408.

Maestrini, V., Luzzini, D., Maccarrone, P. and Caniato, F. (2017) Supply chain performance measurement systems: A systematic review and research agenda, International Journal of Production Economics, Vol. 183, pp. 299-315.

Maestrini, V., Luzzini, D., Shani, A.B.R. and Canterino, F. (2016) The action research cycle reloaded: conducting action research across buyer-supplier relationships, Journal of Purchasing and Supply Management, Vol. 22, No. 4, pp. 289-298.

Maestrini, V., Martinez, V., Neely, A., Luzzini, D., Caniato, F. and Maccarrone, P. (2018) The relationship regulator: a buyer-supplier collaborative performance measurement system, International Journal of Operations \& Production Management.

Mahama, H. (2006) Management control systems, cooperation and performance in strategic supply relationships: a survey in the mines, Management Accounting Research, Vol. 17, No. 3, pp. 315339.

Meekings, A. (1995) Unlocking the potential of performance measurement: A practical implementation guide, Public Money \& Management, Vol. 15, No. 4, pp. 5-12.

Melnyk, S.A., Bititci, U., Platts, K., Tobias, J. and Andersen, B. (2014) Is performance measurement and management fit for the future?, Management Accounting Research, Vol. 25, No. 2, pp. 173-186.

Meredith, J. (1998) Building operations management theory through case and field research, Journal of Operations Management, Vol. 16, No. 4, pp. 441-454. 
Neely, A. (1999) The performance measurement revolution: why now and what next?, International Journal of Operations \& Production Management, Vol. 19, No. 2, pp. 205-228.

Neely, A., Gregory, M. and Platts, K. (1995) Performance measurement system design. A literature review and research agenda, International Journal of Operations \& Production Management, Vol. 15, No. 4, pp. 80-116.

Neely, A., Mills, J., Platts, K., Richards, H., Gregory, M., Bourne, M., and Kennerley, M. (2000) Performance measurement system design: developing and testing a process-based approach, International Journal of Operations \& Production Management, Vol. 20, No. 10, pp. 1119-1145.

Niebecker, K., Eager, D. and Kubitza, K. (2008) Improving cross-company project management performance with a collaborative project scorecard, International Journal of Managing Projects in Business, Vol. 1, No. 3, pp. 368-386.

Niebecker, K., Eager, D. and Moulton, B. (2010) Collaborative and cross-company project management within the automotive industry using the Balanced Scorecard, International Journal of Managing Projects in Business, Vol. 3, No. 2, pp. 328-337.

Nollet, J., Beaulieu, M. and Fabbe-Costes, N. (2017) The impact of performance measurement on purchasing group dynamics: The Canadian experience, Journal of Purchasing and Supply Management, Vol. 23, No. 1, pp. 17-27.

Nudurupati, S.S. and Bititci, U.S. (2005) Implementation and impact of IT-supported performance measurement systems, Production Planning \& Control, Vol. 16, No. 2, pp. 152-162.

Papakiriakopoulos, D. and Pramatari, K. (2010) Collaborative performance measurement in supply chain, Industrial Management \& Data Systems, Vol. 110, No. 9, pp. 1297-1318.

Parung, J. and Bititci, U.S. (2006) A conceptual metric for managing collaborative network, Journal of Modelling in Management, Vol. 1, No. 2, pp. 116-136.

Parung, J. and Bititci, U.S. (2008) A metric for collaborative networks, Business Process Management Journal, Vol. 14, No. 5, pp. 654-674.

Pekkola, S. and Ukko, J. (2016) Designing a performance measurement system for collaborative network, International Journal of Operations \& Production Management, Vol. 36, No. 11, pp. 1410-1434.

Pettigrew, A., Whipp, R. and Rosenfield, R. (1989) Competitiveness and the management of strategic change processes. In: Francis, A. and Tharakan, P.K.M. (eds.), The Competitiveness of European Industry: Country Policies and Company Strategies, Routledge, London.

Pisano, G.P. and Verganti, R. (2008) Which kind of collaboration is right for you?, Harvard Business Review, Vol. 86, No. 12, pp. 78-86.

Pohl, M. and Förstl, K. (2011) Achieving purchasing competence through purchasing performance measurement system design-A multiple-case study analysis, Journal of Purchasing and Supply Management, Vol. 17, No. 4, pp. 231-245. 
Radnor, Z.J. and Barnes, D. (2007) Historical analysis of performance measurement and management in operations management, International Journal of Productivity and Performance Management, Vol. 56, No. 5, pp. 384-396.

Ramsey, J. and Wagner, B. (2009) Organisational Supplying Behaviour: Understanding supplier needs, wants and preferences, Journal of Purchasing and Supply Management, Vol. 15, pp. 127138.

Schneiderman, A. (1999) Why balanced scorecards fail, Journal of Strategic Performance Measurement, Special Edition, pp. 6-11.

Ukko, J. and Pekkola, S. (2016) Customer-centered measurement of service operations: a B2B case study, Operations Management Research, Vol. 9, No. 1, pp. 11-21.

Ukko, J., Pekkola, S., Saunila, M. and Rantala, T. (2015) Performance measurement approach to show the value for the customer in an industrial service network. International Journal of Business Performance Management, Vol. 16, Nos. 2/3, pp. 214-229.

Ukko, J., Tenhunen, J. and Rantanen, H. (2007) Performance measurement impacts on management and leadership - perspectives of management and employees, International Journal of Production Economics, Vol. 110, Nos. 1-2, pp. 39-51.

Verdecho, M.J., Alfaro, J.J. and Rodriguez-Rodriguez, R. (2009) Foundations for collaborative performance measurement, Production Planning \& Control, Vol. 20, No. 3, pp. 193-205.

Yin, R.K. (2003) Case Study Research. Design and Methods, 3rd ed., Sage Publications. 